\title{
An optimized semi-automatic rate method for serum glutathione reductase activity and its application to patients with malignant disease
}

\author{
ALICE DELIDES, RICHARD J. SPOONER, DAVID M. GOLDBERG ${ }^{1}$, AND \\ FRANK E. NEAL \\ From the Department of Chemical Pathology, Royal Hospital, Sheffield and the Department of \\ Radiotherapy, Weston Park Hospital, Sheffield
}

SYNOPSIS An improved and optimized method for serum glutathione reductase is described. The reference range for normal subjects is $47-79 \mathrm{IU} / 1$. The method is more sensitive than conventional enzyme tests in the detection of malignant disease. It was not raised more frequently in patients with clinical evidence of metastases than in those clinically free of such metastases, and it did not seem to correlate with prognosis among those patients who failed to survive six months from the time the analysis was first conducted.

Glutathione reductase (GR; NAD(P)H: glutathione oxido reductase EC 1.6.4.2) is an important flavo enzyme involved, with glucose-6-phosphate dehydrogenase, in the maintenance of a reduced intracellular environment. The glucose-6-phosphate dehydrogenase provides NADPH which allows the reduction of oxidized glutathione (GSSG) using the following reaction:

$\mathrm{GSSG}+\mathrm{NADPH}+\mathrm{H}^{+} \stackrel{\mathrm{GR}}{\rightleftharpoons} 2 \mathrm{GSH}+\cdot \mathrm{NADP}^{+}$

The equilibrium constant strongly favours the formation of reduced glutathione.

Clinical interest in GR has taken several forms. Screening for hereditary erythrocyte GR deficiency has been advocated (Beutler, 1966) although this does not necessarily lead to oxidant-induced haemolytic anaemias (Jaffé, 1968). The prosthetic group of GR is the riboflavin metabolite FAD. The extent of activation of red cell GR by exogenous FAD has been used as a test for riboflavin deficiency (Glatzle et al, 1968; Beutler, 1969; Sauberlich et al, 1972; Heller et al, 1974). Red cell GR is increased in cystic fibrosis patients (Shapiro et al, 1973).

Early work showed that the serum enzyme was elevated in many liver diseases (particularly infective hepatitis), pernicious anaemia, and often to a very high level in malignant disease, especially where

${ }^{1}$ Correspondence to: Dr. D. M. Goldberg, Hospital for Sick Children, 555 University Avenue, Toronto, Ontario, Canada Received for publication 15 July 1975. liver metastases were present (Manso and Wróblewski, 1958; Kerppola et al, 1959; West et al, 1961; Horn et al, 1962).

As approximately $33 \%$ of the patients with cancer in these studies had elevated serum GR levels, and the instrumentation available to the clinical chemist has improved in the decade since these papers were published, the present study was initiated to determine whether, using an automated kinetic determination of GR, the assay was of value in cancer assessment.

\section{Material and Methods}

\section{REAGENTS}

1 Phosphate buffer $(0.15 \mathrm{~mol} / \mathrm{l})$, pH 7.2 at $37^{\circ} \mathrm{C}$. Store at $-20^{\circ} \mathrm{C}$

2 EDTA, disodium salt $(15 \mathrm{mmol} / \mathrm{l})$. Store at $-20^{\circ} \mathrm{C}$

$3 \mathrm{NADPH}$, tetrasodium salt $(10 \mathrm{mmol} / \mathrm{l})$ Boehringer 15501. Prepare freshly each day

4 GSSG (65 mmol/l) Boehringer 15132. Prepare freshly each day

5 Bulk reaction mixture. This is made up each day and for 100 tests should comprise $110 \mathrm{ml}$ Reagent 1, 5.5 ml Reagent 2, $2.75 \mathrm{ml}$ Reagent 3, and $36 \mathrm{ml}$ deionized water.

All assays were performed at $37^{\circ} \mathrm{C}$ with an LKB 8600 Reaction Rate Analyser (LKB Instruments, 
Bromma, Sweden), using an absorbance back-off of $0.3 \mathrm{~A}$ and a reading time of $1 \mathrm{~min}$. Into each cuvet, $1.4 \mathrm{ml}$ Reagent 5 and $50 \mu \mathrm{l}$ of serum were added by an autodilutor. After $10 \mathrm{~min}$ incubation at $37^{\circ} \mathrm{C}$ the reaction was initiated by the addition of 50 $\mu l$ of GSSG. The enzyme activity could be obtained from a recorder tracing by multiplying $\triangle \mathrm{A} / \mathrm{min}$ by a factor of 4823 . In the present study automatic print-out of results was provided by the Optilab Multilog System (Bo Philip Instrumentation, Vallingby, Sweden).

\section{PATIENTS}

All subjects admitted to one unit of a cancer treatment centre over a six-month period had blood taken before commencement of therapy. This was centrifuged, and the serum was removed and stored at $-20^{\circ} \mathrm{C}$ before analysis. Replicate analysis on 20 samples before and after storage for several months resulted in no significant change in activity. Aspartate transaminase (AsT), lactate dehydrogenase (LDH), and alkaline phosphatase (ALP) activities were assayed using the SMA 12/60 (Technicon Instruments Ltd). Reference ranges for this laboratory are 10-50 IU/1, 100-225 IU/1, and 28-100 IU/1 respectively.

Careful clinical assessment of the subjects was carried out, and the salient features of their disease are summarized in table I. Only one subject had overt hepatic metastases when first examined. Sites of metastases were superficial glands (6), peritoneal nodes (5), pelvis (4), bones (3), brain (3), bladder (1), lungs (1), and widespread (1).

\section{TISSUE PREPARATION}

Purified preparations of human erythrocyte GR were made using the method of Scott et al (1963). The source of human liver GR was a high-speed supernate $(100000 \times g$ for $1 \mathrm{hr})$ of fresh postmortem liver homogenized $1: 3$ in ice-cold sucrose $(0 \cdot 25$ $\mathrm{mol} / 1)$.

\begin{tabular}{|c|c|c|c|c|}
\hline \multirow{2}{*}{$\begin{array}{l}\text { Location } \\
\text { of Cancer }\end{array}$} & \multirow{2}{*}{$\begin{array}{l}\text { Males } \\
(\%)\end{array}$} & \multirow{2}{*}{$\begin{array}{l}\text { Mean } \\
\text { Age }\end{array}$} & \multicolumn{2}{|l|}{ No. with } \\
\hline & & & Metastases & $\begin{array}{l}\text { No Detectable } \\
\text { Metastases }\end{array}$ \\
\hline $\begin{array}{l}\text { Respiratory } \\
\text { tract }\end{array}$ & 95 & 60 & 4 & 17 \\
\hline $\begin{array}{l}\text { Urogenital } \\
\text { tract }\end{array}$ & 56 & 52 & 6 & 10 \\
\hline Breast & 0 & 59 & 1 & 9 \\
\hline $\begin{array}{l}\text { Digestive } \\
\text { tract }\end{array}$ & 62 & 62 & 3 & 5 \\
\hline $\begin{array}{l}\text { Reticulo- } \\
\text { endothelial }\end{array}$ & 72 & 49 & 5 & 2 \\
\hline Others & 33 & 46 & 3 & 3 \\
\hline Total & & & 22 & 46 \\
\hline
\end{tabular}

Table I Classification of cancer patients at time Serum $G R$ was first assayed

\section{Results}

CHOICE OF BUFFER

Initial studies showed that phosphate was superior to triethanolamine and PIPES (piperazine-N, $\mathrm{N}^{\prime}$-bis (2-ethane-sulphonic acid)), and that varying the molarity between 0.1 and $0.3 \mathrm{~mol} / 1$ was without effect.

The inclusion of EDTA in the reaction mixture at a final concentration of $0.5 \mathrm{mmol} / \mathrm{l}$ enhanced enzyme activity and raised the $\mathrm{pH}$ optimum (fig 1). This shift in pH optimum occurring when EDTA is included in the reaction mixture allows GR from all sources to be analysed at $\mathrm{pH} 7 \cdot 2$, and this minimizes blank reactions due to spontaneous hydrolysis of NADPH.

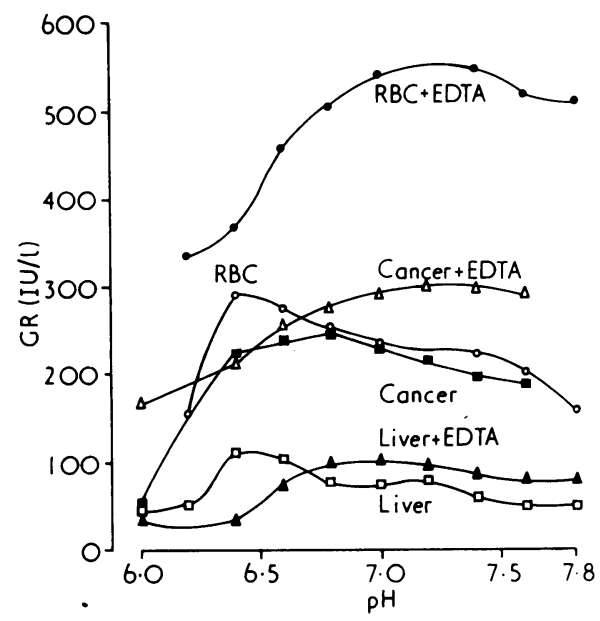

Fig 1 Influence of EDTA at a final concentration of $0.5 \mathrm{mmol} / \mathrm{l}$ on activity of $G R$ under the conditions of the proposed method upon serum from a patient with cancer and one with acute liver disease, and upon a red blood cell haemolysate $(R B C)$.

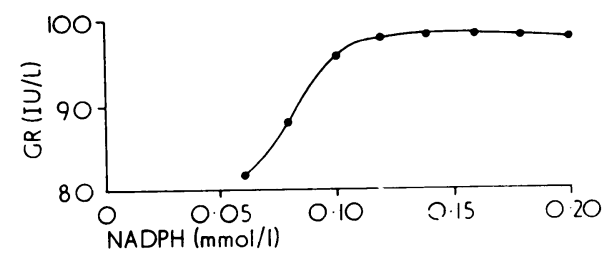

Fig 2 Relation of NADPH concentration to serum $G R$ activity, with all other conditions as in the proposed method. 
CHOICE OF SUBSTRATE CONCENTRATION

NADPH was optimal at final concentrations above $0.12 \mathrm{mmol} / 1$ (fig 2). GSSG was optimal at final concentrations above $0.54 \mathrm{mmol} / 1$ (fig 3 ).

EFFECT OF SALTS ON SERUM GR Increasing concentrations of potassium and sodium chloride were inhibitory $(30 \%$ and $80 \%$ respectively at $0.1 \mathrm{~mol} / \mathrm{l})$. Potassium oxalate and acetate at the same concentration caused approximately $20 \%$ activation of the serum enzyme. Chloride ions were thus inhibitory to serum GR activity.

\section{EFFECT OF ENZYME ACTIVATORS}

Dithioerythritol was included in the reaction mixture to a final concentration of $2 \mathrm{mmol} / \mathrm{l}$ and had no significant effect on the activity of the serum enzyme.

FAD has been shown to activate red cell GR (Glatzle et al, 1968; Beutler, 1969). Inclusion of FAD in the reaction mixture up to a final concentration of $10 \mu \mathrm{mol} / \mathrm{l}$ (concentrations above this were slightly inhibitory) had no effect on 37 of 38 randomly selected sera. The single exception was activated by $20 \%$ and $65 \%$ at 2 and $10 \mu \mathrm{mol} / 1$ respectively. The patient concerned had a prostatic carcinoma, and riboflavin deficiency could not be ruled out.

\section{CHARACTERISTICS OF THE PROPOSED}

\section{METHOD}

Enzyme activity is linearly related to the amount of serum taken, to an absorbance change of 0.310 per min. This corresponds to an activity of $1500 \mathrm{IU} / 1$. Data for within-batch precision are given in table II

\begin{tabular}{llll}
\hline No. of Samples & $\begin{array}{l}\text { Mean Activity } \\
(I U / l)\end{array}$ & $S D$ & $\begin{array}{l}C V \\
(\%)\end{array}$ \\
\hline 18 & $52 \cdot 7$ & $3 \cdot 72$ & $7 \cdot 1$ \\
15 & $140 \cdot 0$ & $6 \cdot 6$ & $4 \cdot 7$ \\
15 & 252.5 & $6 \cdot 3$ & $2 \cdot 5$ \\
\hline
\end{tabular}

Table II Within-batch precision of GR assay

for three levels of activity. The normal range was determined using 63 fasting laboratory staff. Serum was stored at $-20^{\circ} \mathrm{C}$ and assayed in batches since no significant loss of activity was detected in 20 samples stored at $-20^{\circ} \mathrm{C}$ for periods of up to 19 months. No sex or age dependance was observed, and the results were combined to give a reference range (mean \pm 2SD) of 47-79 IU/l.

SERUM GR IN CANCER PATIENTS

Of the 68 patients examined, $39(58 \%)$ had a serum GR activity above the reference range established

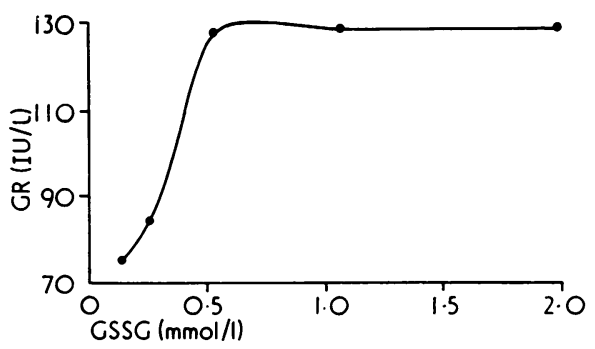

Fig 3 Relation of GSSG concentration to serum GR activity, with all other conditions as in the proposed method.

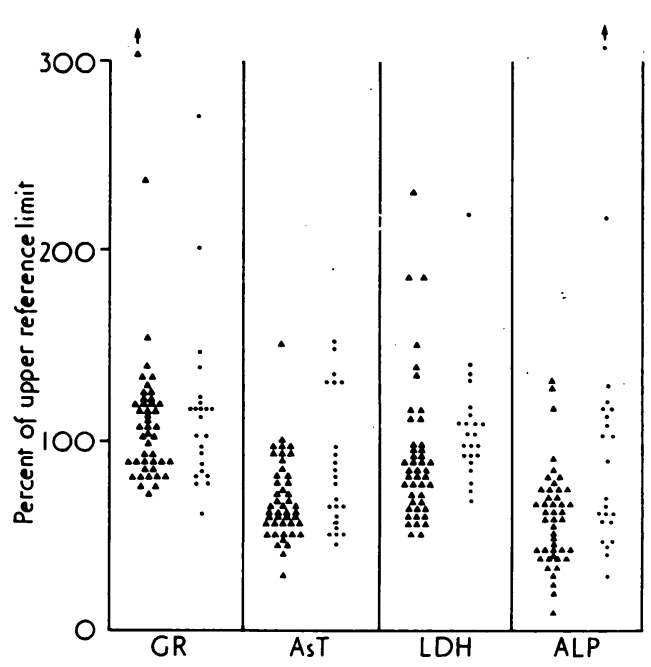

Fig 4 Distribution of enzyme activity in the cancer patients studied: patients with no detectable metastases $\Delta$ and those with metastases $\mathbf{O}$.

for normal subjects. Comparable data for the other enzymes were AsT 7 (10\%), LDH 22 (31\%), and ALP $13(19 \%)$. The distribution of enzyme values in all subjects is shown in fig 4 . Of the subjects with raised

\begin{tabular}{llrlrll}
\hline \multicolumn{7}{c}{ Percentage with Raised Serum Enzymes } \\
\cline { 2 - 7 } & GR & AsT & LDH & ALP & $\begin{array}{c}\text { GR \& } \\
\text { LDH }\end{array}$ & None \\
\hline Dead (36) & 57 & 20 & 48 & 29 & 19 & 29 \\
Alive (32) & 47 & 0 & 18 & 9 & 19 & 47 \\
\hline
\end{tabular}

Table III Relation between abnormal enzymes and prognosis after six months

${ }^{1}$ No. of cases in parentheses 
serum GR activity, $15 \%$ had an elevated AsT, $51 \%$ an elevated $\mathrm{LDH}$, and $20 \%$ an elevated ALP. Of the 29 with a normal serum GR activity, only one had an elevated AsT, two an elevated LDH, and five an elevated ALP. Of those with a normal GR and elevated ALP, only one was known to have bony metastases.

Table III shows the outcome of the disease processes six months after the initial assessment. An enzyme elevation indicates a poorer prognosis; in particular, all seven patients with an AsT elevation died within six months of the analysis.

In view of previous emphasis on LDH as an indicator of possible malignant disease (Ticktin and Trujillo, 1970), a comparison was made of the data for this enzyme and for GR in the same patients (fig 5). In addition, an analysis was conducted on the regression and correlation between the two estimations in subjects grouped according to presence or absence of clinically detectable metastases (table IV). This showed that, on the whole, there was not a close relationship between the two. The factors leading to their elevation in cancer subjects therefore appear to be different, and this implies that more information can be obtained by assaying both than one alone.

\section{Discussion}

During the last decade there have been many

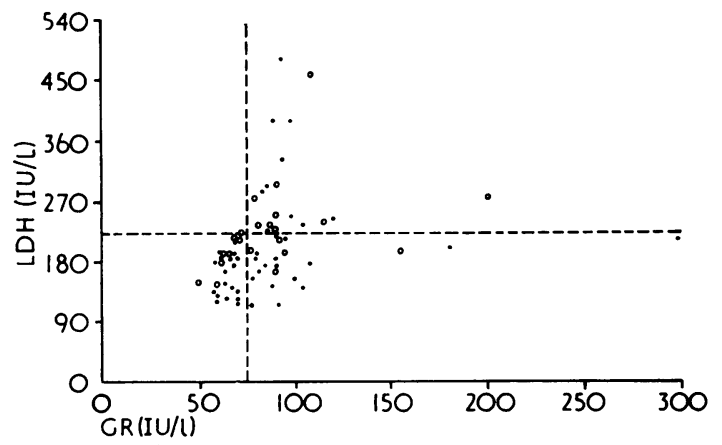

Fig 5 Plot of serum $L D H$ and $G R$ activities in the cancer patients studied: patients with no detectable metastases and those with metastases $\bigcirc$. Regression and correlation data are given in table IV. attempts to find a laboratory test capable of identifying those patients with malignant disease in an apparently normal population. Several of these have involved the measurement of serum enzymes or isoenzymes, the two most popular in this group being LDH (Ticktin and Trujillo, 1970) and the Regan isoenzyme of ALP (Fishman et al, 1968). These suffer the disadvantages of poor specificity and a low incidence respectively.

Early work on serum GR showed that one-third of patients with neoplastic disease had elevated activity. The present study was initiated to determine the clinical value of this assay using improved methodology, since current methods proved to be suboptimal, unsuitable for application to reaction rate analysers, or optimized for the erythrocyte enzyme. The use of a reaction rate analyser for the estimation of erythrocyte GR has been described (Brewster et al, 1974). The method is optimized for very small sample volumes, since high concentrations of haemolysates give unacceptably high initial absorbances, and is not directly applicable to serum. A colourimetric method based upon the quantitative liberation of chlorpromazine from a preformed coloured palladium-chlorpromazine complex by the reduced glutathione produced in the reaction has been described (Lee et al, 1975). This method is independent of the initial absorbance and has been applied to the estimation of both serum and erythrocyte GR activities.

The inclusion of EDTA in the reaction mixture has long been part of erythrocyte GR assays, and its inclusion in the serum assay is justified by the increase in activity and the shift in pH optimum to a more alkaline region with improved stability of NADPH. Earlier methods employed conditions differing from those we found to be optimal, and a comparison of these with our own is presented in table V.

The observation that the serum enzyme is not $\mathrm{O}$ activated by FAD, unlike the erythrocyte enzyme (Glatzle et al, 1968; Beutler, 1969), may reflect a higher extracellular FAD concentration. The GR $N$ activity of rat liver homogenates has been shown to $\Omega$ be unaffected by exogenous FAD (Menendez et al, $N$ 1974).

The results obtained from patients with cancer 0 demonstrate the superiority of serum GR estima-

\begin{tabular}{|c|c|c|c|c|c|}
\hline Population & Number & Slope & Intercept & $\begin{array}{l}\text { Correlation } \\
\text { Coefficient }\end{array}$ & $\begin{array}{l}\text { Level of Significance } \\
\text { (P) }\end{array}$ \\
\hline $\begin{array}{l}\text { Without metastases } \\
\text { With metastases } \\
\text { Combined }\end{array}$ & $\begin{array}{l}45 \\
23 \\
68\end{array}$ & $\begin{array}{l}0.41 \\
0.72 \\
0.50\end{array}$ & $\begin{array}{l}109 \cdot 5 \\
137 \cdot 6 \\
119 \cdot 0\end{array}$ & $\begin{array}{l}0 \cdot 204 \\
0 \cdot 376 \\
0 \cdot 247\end{array}$ & $\begin{array}{l}>0.05 \\
>0.05 \\
<0.05\end{array}$ \\
\hline
\end{tabular}

Table IV Data for regression analysis of $L D H$ on $G R$ 


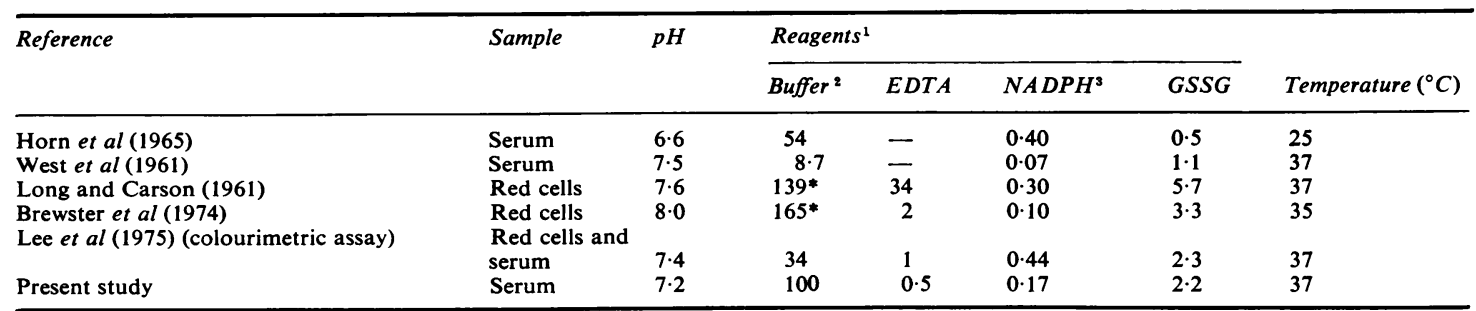

Table V Comparison of existing methods for estimation of $G R$

${ }^{1}$ Final concentrations (mmol/1)

${ }^{2}$ Phosphate except where marked *, these being tris

${ }^{3} \mathrm{NADPH}$ concentrations $>0.25 \mathrm{mmol} / 1$ yield absorbances of $>1.55$, the maximum acceptable on the LKB

tions over LDH in the diagnosis of malignant disease; these two enzymes are much more likely to be raised than either AsT or ALP. Analysis of the individual raised serum GR values showed them to be randomly distributed throughout the various categories of malignancy given in table I. It could not be used as an index of possible metastases.

The level of serum GR activity was of no value in assessing the eventual outcome, and in fact GR was a worse prognostic index than any of the other enzymes assayed. AsT was the most promising in this regard since all the patients who had an elevated AsT died within six months of the sample being taken. However, the high incidence of raised serum GR among cancer patients demonstrated in this study suggests that it may be of value in population screening. Since it is raised in liver disease and blood dyscrasias (Manso and Wróblewski, 1958; Kerppola et al, 1959; West et al, 1961; Horn et al, 1962), serum GR cannot be regarded as a cancer specific test, but it deserves to replace LDH in multiphasic biochemical profiling. A true assessment of its diagnostic value will emerge only when it is applied to a general hospital population rather than to the restricted case material of a cancer-treatment centre.

We thank Dr Helen Munro and Dr Zoe Randall for help in this study.

\section{References}

Beutler, E. (1966). A series of new screening procedures for pyruvate kinase deficiency, glucose-6-phosphate dehydrogenase deficiency, and glutathione reductase deficiency. Blood, 28, 553-562.

Beutler, E. (1969). The effect of flavin compounds on glutathione reductase activity: in vivo and in vitro studies. J. clin. Invest., 48, 1957-1966.

Brewster, M. A., Berry, D. H., and Murphey, M. N. (1974). Automated reaction rate analysis of erythrocyte glucose-6phosphate dehydrogenase and glutathione reductase activities. Biochem. Med., 10, 229-235.

Fishman, W. H., Inglis, N. I., Stolbach, L. L., and Krant, M. J. (1968). A serum alkaline phosphatase isoenzyme of human neoplastic cell origin. Cancer Res., 28, 150-154.
Glatzle, D., Weber, F., and Wiss, O. (1968). Enzymatic test for the detection of a riboflavin deficiency. NADPHdependant glutathione reductase of red blood cells and its activation by FAD in vitro. Experientia (Basel), 24, 1122.

Heller, S., Salkeld, R. M., and Körner, W. F. (1974). Riboflavin status in pregnancy. Amer. J. clin. Nutr., 27, 12251230.

Horn, H. D., Mainzer, K., and Langrehr, D. (1962). Über die Glutathionreduktase im Serum des Menschen: ein Beitrag zur Differentialdiagnose der Lebererkrankungen. Klin. Wschr., 40, 985-995.

Jaffé, E. R. (1968). In Hereditary Disorders of Erythrocyte Metabolism, edited by E. Beutler, pp. 205-207. Grune and Stratton, New York.

Kerppola, W., Nikkilä, E. A., and Pitkänen, E. (1959). Serum TPN-linked enzymes: glucose-6-phosphate dehydrogenase, isocitric dehydrogenase and glutathione reductase activities in health and in various disease states. Acta med. scand., 164, 357-365.

Lee, K. T., Tan, I. K., and Seet, A. M. (1975). A new colorimetric method for the determination of NADH/NADPH dependant glutathione reductase in erythrocytes and in plasma. Clin. chim. Acta., 58, 101-108.

Long, W. K. and Carson, P. E. (1961). Increased erythrocyte glutathione reductase activity in diabetes mellitus. Biochem. biophys. Res. Commun., 5, 394-399.

Manso, C. Wróblewski, F. (1958). Glutathione reductase activity in blood and body fluids. J. clin. Invest., 37, 214 218.

Menendez, C. E., Hacker, P., Sonnenfeld, M., McConnell, R., and Rivlin, R. S. (1974). Thyroid hormone control of glutathione reductase activity in rat erythrocytes and liver. Amer.J. Physiol., 226, 1480-1483.

Sauberlich, H. E., Judd, J. H., Jr., Nichoalds, G. E., Broquist, H. P., and Darby, W. J. (1972). Application of the erythrocyte glutathione reductase assay in evaluating riboflavin nutritional status in a high school student population. Amer. J. clin. Nutr., 25, 756-762.

Scott, E. M., Duncan, I. W., and Ekstrand, V. (1963). Purification and properties of glutathione reductase of human erythrocytes. J. biol. Chem., 238, 3928-3933.

Shapiro, B. L., Smith, Q. T., and Warwick, W. J. (1973). Red cell glutathione and glutathione reductase in cystic fibrosis. Proc. Soc. exp. Biol. (N.Y.), 144, 181-183.

Ticktin, H. E. and Trujillo, N. P. (1970). Enzymes in neoplastic and surgical diseases. In Diagnostic Enzymology, edited by E. L. Coodley, pp. 205-222. Lea and Febiger, Philadelphia.

West, M., Berger, C., Rony, H., and Zimmerman, H. J. (1961). Serum enzymes in disease. VI. Glutathione reductase in sera of normal subjects and of patients with various diseases. J. Lab. clin. Med., 57, 946-954. 